University of Nebraska - Lincoln

DigitalCommons@University of Nebraska - Lincoln

\title{
Genotype and Genotype x Environment Interaction Effects on Forage Yield and Quality of Intermediate Wheatgrass in Swards
}

\author{
Kenneth P. Vogel \\ University of Nebraska-Lincoln, kvogel1@unl.edu \\ Patrick E. Reece \\ Panhandle Research and Extension Center, preece1@unl.edu \\ James T. Nichols \\ West Central Research and Extension Center
}

Follow this and additional works at: https://digitalcommons.unl.edu/usdaarsfacpub

\footnotetext{
Vogel, Kenneth P.; Reece, Patrick E.; and Nichols, James T., "Genotype and Genotype x Environment Interaction Effects on Forage Yield and Quality of Intermediate Wheatgrass in Swards" (1993). Publications from USDA-ARS / UNL Faculty. 1904.

https://digitalcommons.unl.edu/usdaarsfacpub/1904
}

This Article is brought to you for free and open access by the U.S. Department of Agriculture: Agricultural Research Service, Lincoln, Nebraska at DigitalCommons@University of Nebraska - Lincoln. It has been accepted for inclusion in Publications from USDA-ARS / UNL Faculty by an authorized administrator of DigitalCommons@University of Nebraska - Lincoln. 


\title{
Genotype and Genotype $\times$ Environment Interaction Effects on Forage Yield and Quality of Intermediate Wheatgrass in Swards
}

\author{
Kenneth P. Vogel,* Patrick E. Reece, and James T. Nichols
}

\begin{abstract}
Genetic differences among cultivars or strains for specific traits can be significantly reduced or increased by differential genotypic responses to environments. The objective of this study was to determine the relative magnitude of genotype and genotype $x$ environment interaction effects, which are due to differential responses, on forage yield and quality of intermediate wheatgrass [Thinopyrum intermedium (Host) Barkworth \& D.R. Dewey] when grown in seeded swards in the central Great Plains. Thirty-four strains (genotypes), which included cultivars, experimental strains, and PI lines, were grown in replicated trials at Mead, North Platte, and Alliance, NE. The three sites differed markedly in precipitation and length of growing season. There were significant differences among strains for all evaluated traits. Genotype $x$ location and genotype $\times$ year interaction effects were not significant for in vitro dry matter digestibility (IVDMD), indicating that this trait is quite stable across environments. Genotype $x$ location interaction effects were significant for forage yield and protein concentration; genotype $x$ year effects were significant for forage yield. Spearman rank correlations, used to test for consistency of ranking of the strains across environments, were high and significant for IVDMD, but were low and usually not significant for forage yield. Improving IVDMD should be emphasized in intermediate wheatgrass breeding programs, since there is substantial genetic variation for IVDMD, it is stable across environments, and it can improve livestock production per hectare.
\end{abstract}

IN NTERMEDIATE WHEATGRASS is an introduced cool-season grass adapted to the Great Plains and the Intermountain West regions of the USA and to much of the grasslands of central and western Canada. Glabrous and pubescent types exist within the species and were previously classified by Hitchcock (1951) as Agropyron intermedium (Host) Beauv. and A. trichophorum (Link) Richt., respectively. The revised classification of Dewey

K.P. Vogel, USDA-ARS, 332 Keim Hall, Dep. of Agronomy, Univ. of Nebraska, Lincoln, NE 68583; P.E. Reece, Panhandle Research and Extension Center, 4502 Ave. 1, Scottsbluff, NE 69361; and J.T. Nichols, West Central Research and Extension Center, Rt 4, Box 46A, North Platte, NE 69101. Contribution of the USDA-ARS and the University of Nebraska. Published as Paper no. 9833, Journal Series, Nebraska Agric. Exp. Stn. Received 23 Jan. 1992. *Corresponding author.

Published in Crop Sci. 33:37-41 (1993).
(1984) and Barkworth and Dewey (1985), based on both morphological and phylogenetic relationships, is used in this report.

Intermediate wheatgrass is used almost exclusively as a range and pasture grass and for hay production. Until this year, however, no cultivars have been released with improved forage quality for livestock production (Hanson, 1972; Lawrence, 1982). The cultivar Manska was released for seed production in 1992 based on improved IVDMD and beef cattle gains (U.S. Dep. of Agric., Announcement of the Release of 'Manska' pubescent intermediate wheatgrass, 1992).

Evidence of differences among strains for IVDMD has been documented previously. Wurster et al. (1971) reported significant differences for IVDMD between forage of 'Oahe' and 'Greenar' intermediate wheatgrass. Thaden et al. (1975) reported significant differences in IVDMD of both tillers and flag leaves of a five-genotype diallel cross of intermediate wheatgrass. They concluded that it should be possible to breed for improved forage IVDMD in intermediate wheatgrass and that whole tillers rather than tiller parts should be used in the assay. Vogel et al. (1986) reported that substantial genetic variability exists among intermediate wheatgrass germplasm accessions for IVDMD, but not for protein content.

Information on the relative magnitude of genotype and genotype $x$ environment interaction effects on forage quality and yield traits is limited. Heinrichs et al. (1962) evaluated 47 half-sib progenies from three separate polycross nurseries in sward plots in three environments in Saskatchewan, Canada. Significant differences existed among the populations and half-sib progenies for 1stand 2 nd-yr total forage yields, as well as for 1st-yr seed yields and plant height. No forage quality data were reported. Vogel et al. (1986) evaluated 36 diverse strains, which included plant introductions, for forage yield and IVDMD in space-transplanted plots in two diverse central Great Plains environments. Strain $\times$ location and strain $\times$ year interaction effects were significant for firstcut forage yield, but not for IVDMD. Spearman rank

Abbreviations: ANOVA, analyses of variance; IVDOM, in vitro digestible organic matter; IVDMD, in vitro dry matter digestibility. 
correlation coefficients of the strains over environments were 0.77 for both forage yield and IVDMD, indicating that the strains ranked similarly for yield and IVDMD in the two diverse environments. Karn and Berdahl (1984) evaluated eight intermediate wheatgrass clones in replicated miniplots in 1980 and 1981 at Mandan, ND for IVDOM. Significant differences existed among the clones for IVDOM for the 2-yr period and clone $\times$ year effects were not significant. Rice and Brown (1985) evaluated 20 clones of intermediate wheatgrass in Alabama for a 2-yr period for forage $\mathrm{N}$, acid detergent fiber, neutral detergent fiber, hemicellulose, $\mathrm{K}, \mathrm{Mg}, \mathrm{Ca}, \mathrm{P}$, and $\mathrm{S}$. Clone $\times$ year effects were significant for all traits except $\mathrm{K}$ and $\mathrm{S}$.

The previously reported research indicates that there is genetic variation among intermediate wheatgrasses for forage quality as measured by IVDMD or IVDOM and that it appears to be relatively stable across environments when the plants are grown in space-transplanted nurseries or miniplots. Intermediate wheatgrass is seeded and utilized for hay or grazing in swards. The objectives of this study were to determine the relative magnitude of genotype and genotype $\times$ environment interaction effects on forage yield and quality of intermediate wheatgrasses cultivars and elite strains grown in seeded, sward plots under typical hayland management in the central Great Plains of the USA.

\section{MATERIALS AND METHODS}

Thirty-four cultivars, experimental strains, and PI lines were grown in replicated $(r=4)$ trials at Mead, North Platte, and Alliance, NE. This included all released cultivars for which seed was available, plus experimental strains from breeding programs in the USA and Canada. The experimental strains included six plant introduction lines that had the highest forage yields in the space-planted study reported previously by Vogel et al. (1986). The soils at the sites were a Sharpsburg siltyclay soil (fine, montmorillonitic, mesic Typic Arguidoll) at Mead, Holdrege silt loam (fine-silty, mixed, mesic Typic Argiustoll) at North Platte, and a Keith soil (fine-silty, mixed, mesic Aridic Argiustoll) at Alliance.

The grasses were seeded in small plots, 1.5 by $4.5 \mathrm{~m}$, in the fall of 1980 . Seeding rate was 400 pure live seeds $\mathrm{m}^{-2}$. Plots were harvested for forage yield in 1982 and 1983 using a flail-type plot harvester with a cutting height of $10 \mathrm{~cm}$. First harvests were made during the last week of June or the first week of July, following head emergence. Regrowth was harvested in late fall only at Mead and is not reported. Regrowth at the other sites was limited because of reduced precipitation. Plots were fertilized with $\mathrm{NH}_{4} \mathrm{NO}_{3}$ in April each year. Fertilization rates were $112 \mathrm{~kg} \mathrm{ha}^{-1} \mathrm{~N}$ for Mead and North Platte and $67 \mathrm{~kg} \mathrm{ha}^{-1} \mathrm{~N}$ for Alliance, which is in the recommended range for these locations.

Subsamples for determination of dry matter, protein, and IVDMD consisted of $\approx 200 \mathrm{~g}$ of freshly harvested forage that was weighed in the field, dried in a forced-air oven at $65^{\circ} \mathrm{C}$, and reweighed. Subsamples were composited by combining a minimum of four grab samples per plot. Dry matter content was determined, and yields were reported on a dry-weight basis. Dried samples were ground through a Wiley' ${ }^{1}$ mill with a 1-mm screen. In vitro dry matter digestibility was determined by using the Tilley and Terry (1963) procedure with minor modifications: $\mathrm{HgCl}_{2}$ and $\mathrm{NaCO}_{3}$ were not added after the first digestion stage. Proteins are Kjeldahl N $\times 6.25$ (AOAC, 1960).

\footnotetext{
1 Mention of a trademark, proprietary product, or vendor does not constitute a guarantee or warranty of the product by the USDA or the Univ. of Nebraska and does not imply its approval to the exclusion of other products or vendors that may also be suitable.
}

Digestible dry matter yield was determined as: Digestible yield $=$ Yield $\times$ IVDMD $\%$. The Nebraska Index (NE Index; Roth, 1971) was used to combine yield and IVDMD into a single value in which both are equally weighted:

$$
\begin{aligned}
\text { NE Index }= & \frac{(\text { yield }-\bar{X} \text { yield })}{s \text { yield }} \\
& +\frac{(\text { IVDMD }-\bar{X} \text { IVDMD })}{s \text { IVDMD }}
\end{aligned}
$$

where $\mathbf{X}$ and $\mathrm{s}$ are the location mean and standard deviation for a single year, respectively.

Analyses of variance were used to evaluate results at a single location over years and over years for all locations. The overyears ANOVAs were all analyzed as split plots in time (Steel and Torrie, 1960). Strains, locations, and years were considered to be random effects in all ANOVAs. Strains were considered random, because only 11 of the strains were released cultivars; the others were experimental lines representing a sample of the potential population of experimental strains. Approximate $F$-tests (Snedecor and Cochran, 1967, p. 364-367) were used to test the strain component of variance for both single location and multilocation ANOVAs. Variance components were calculated from mean squares using standard procedures (Becker, 1984). Pearson correlation coefficients were calculated between traits using strain means for each year and location. Rank correlations were also determined between locations for each trait using Spearman rank correlations (Steel and Torrie, 1960).

\section{RESULTS AND DISCUSSION}

The three sites differed markedly in precipitation and length of growing season during this study, as indicated in Table 1. There is a significant climatic gradient from east to west across the Great Plains; altitude increases, precipitation decreases, and growing season decreases from east to west (Lawson, 1977; Neild, 1977). The region can have large year-to-year variation in climate. Intermediate wheatgrass is the only cool-season grass currently recommended for use across this climatic gradient in the Central Great Plains.

There were significant differences among strains for forage yield, IVDMD, and protein concentrations at each site and across sites (Tables 2 and 3). Major yield differences existed among locations, apparently due to precipitation differences. There were no differences among the strains for dry matter concentration. All strains headed within a period of $2 \mathrm{~d}$, except for 'Tegmar', which headed 5 to $10 \mathrm{~d}$ earlier than the other strains (data not shown). There were significant differences among strains for NE Index values at Mead, North Platte, and averaged over sites (Table 2).

Genotype $\times$ location interaction effects were signif-

Table 1. Annual precipitation, growing season length, and altitude of the Nebraska research sites in 1982 and $1983 . \dagger$

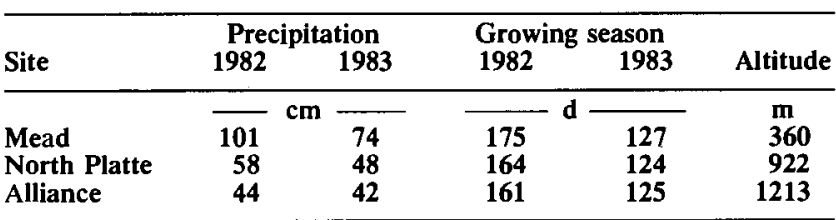

† National Oceanic and Atmospheric Administration 1982 and 1983 Growing season is the days between $0{ }^{\circ} \mathrm{C}$ in the spring and $0{ }^{\circ} \mathrm{C}$ in the fall. 
Table 2. Means and ranges of first harvest agronomic traits of intermediate wheatgrass strains grown in sward plots at three locations in Nebraska in 1982 and 1983.

\begin{tabular}{|c|c|c|c|c|c|}
\hline Location & Statistics & $\begin{array}{l}\text { Forage } \\
\text { Yield }\end{array}$ & IVDMD & Protein & NE Index $\dagger$ \\
\hline & & Mg ha-1 & \multicolumn{2}{|c|}{$-\mathrm{g} \mathrm{kg}^{-1}-$} & \\
\hline Mead & $\begin{array}{l}\text { Mean } \\
\text { Range } \\
\text { CV \% } \\
\text { LSD .05 }\end{array}$ & $\begin{array}{c}7.4^{* *} \\
4.8 \text { to } 8.6 \\
17 \\
1.0\end{array}$ & $\begin{array}{c}566^{* *} \\
535 \text { to } 593 \\
4 \\
19\end{array}$ & $\begin{array}{c}90^{* *} \\
84 \text { to } 96 \\
3 \\
2\end{array}$ & $\begin{array}{c}0.0^{* * \dagger} \\
-3.6 \text { to } 1.2 \\
-\ddagger \\
-\end{array}$ \\
\hline North Platte & $\begin{array}{l}\text { Mean } \\
\text { Range } \\
\text { CV \% } \\
\text { LSD .05 }\end{array}$ & $\begin{array}{l}5.5^{* *} \\
3.7 \text { to } 6.1 \\
16 \\
0.7\end{array}$ & $\begin{array}{c}574^{*} \\
551 \text { to } 602 \\
4 \\
19\end{array}$ & $\begin{array}{c}68^{*} \\
58 \text { to } 72 \\
10 \\
5\end{array}$ & $\begin{array}{c}0.0^{* *} \\
-2.8 \text { to } 1.6 \\
-\ddagger \\
-\end{array}$ \\
\hline Alliance & $\begin{array}{l}\text { Mean } \\
\text { Range } \\
\text { CV \% } \\
\text { LSD .05 }\end{array}$ & $\begin{array}{c}3.1 * * \\
3.0 \text { to } 5.6 \\
19 \\
0.5\end{array}$ & $\begin{array}{c}563^{*} \\
516 \text { to } 585 \\
7 \\
33\end{array}$ & $\begin{array}{c}75^{* *} \\
69 \text { to } 79 \\
7 \\
4\end{array}$ & $\begin{array}{c}0.0 \\
-1.5 \text { to } 5.2 \\
-\ddagger \\
-\end{array}$ \\
\hline Overall & $\begin{array}{l}\text { Mean } \\
\text { Range } \\
\text { CV \% } \\
\text { LSD .05 }\end{array}$ & $\begin{array}{c}5.3^{* *} \\
3.8 \text { to } 6.4 \\
10 \\
0.4\end{array}$ & $\begin{array}{c}567^{* *} \\
535 \text { to } 585 \\
20 \\
7\end{array}$ & $\begin{array}{c}78^{* *} \\
72 \text { to } 84 \\
5 \\
2\end{array}$ & $\begin{array}{c}0.0^{* *} \\
-2.6 \text { to } 2.1 \\
-\ddagger \\
-\end{array}$ \\
\hline
\end{tabular}

*,** Significant at the 0.05 and 0.01 levels of probability, respectively, according to $F$-test for strains.

$\dagger$ NE Index $=[($ yield $-\bar{X}$ yield $(/ s$ yield $]+[$ (IVDMD $-\bar{X}$ IVDMD $) /$

$s$ IVDMD], where $\bar{X}=$ location mean and $s=$ standard deviation. $\ddagger \mathrm{CV}$ not determined, because $\bar{X}=0.0$ for index values.

icant for forage yield and protein concentration in the combined analyses over years and locations (Table 3 ). Genotype $\times$ year effects were significant only for forage yield. Genotype $\times$ location and genotype $\times$ year interaction effects were not significant for IVDMD and NE Index values (Table 3 ), indicating that these traits are relatively consistent over these contrasting environments. The genotype $\times$ year interaction effect for forage yield was significant, but the variance component for this effect was only one-fourth and one-half the magnitude of the genotype and genotype $\times$ location interaction variances, respectively. Thus, the genotype $\times$ year interaction effects for forage yield, although statistically significant, were relatively less important than the genotype and the genotype $\times$ location interaction effects.

Digestible yield was highly correlated with yield, indicating that it is more a measure of yield than of forage quality (Table 4). NE Index values had similar correlations with yield and IVDMD showing that it weights both traits approximately the same. IVDMD was not corre-

Table 3. Mean squares (MS), and variance components (VC) for the combined analyses over locations and years for firstharvest traits of intermediate wheatgrass.

\begin{tabular}{|c|c|c|c|c|c|c|c|c|c|}
\hline \multirow[b]{2}{*}{ Source } & \multirow[b]{2}{*}{ df } & \multicolumn{2}{|c|}{ Forage yield } & \multicolumn{2}{|c|}{ IVDMD } & \multicolumn{2}{|c|}{ Protein } & \multicolumn{2}{|c|}{$\mathrm{NE}$ index $\dagger$} \\
\hline & & MS & $\overline{\mathrm{VC}}$ & MS & $\mathrm{VC}$ & MS & $\overline{V C}$ & MS & VC \\
\hline & & $-M$ & & & 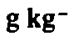 & & & & \\
\hline & $\begin{array}{r}2 \\
33\end{array}$ & 314. & & & 39 & & 3 & & 0. \\
\hline $\begin{array}{l}\mathrm{L} \times \mathbf{G} \\
\mathrm{Year}(\mathrm{Y}) \\
\mathbf{Y} \times \mathbf{L} \\
\mathbf{Y} \times \mathbf{G} \\
\mathbf{Y} \times \mathbf{L} \times\end{array}$ & $\begin{array}{r}66 \\
1 \\
2 \\
33 \\
66\end{array}$ & $\begin{array}{c}0.19^{* *} \\
36.66 \\
13.35 \\
0.17^{* *} \\
0.07\end{array}$ & 0.06 & $\begin{array}{c}134 \\
1398 \\
27773 \\
93 \\
122\end{array}$ & 6 & $\begin{array}{c}11 * * \\
167 \\
1740 \\
7 \\
7\end{array}$ & 0 & $\begin{array}{l}0.01 \\
0.44 \\
0.29\end{array}$ & 0.05 \\
\hline
\end{tabular}

*,** Significant at the 0.05 and 0.01 levels of probability, respectively, for genotype and genotype interaction effects.

$+\mathrm{NE}$ Index $=[$ (yield $-\bar{X}$ yield $) / s$ yield $]+[($ IVDMD $-\bar{X}$ IVDMD $) /$

$s$ IVDMD], where $\bar{X}=$ location mean and $s=$ standard deviation.
Table 4. Phenotypic correlations between first harvest traits of intermediate wheatgrass strains for three central great plains locations for two years.

\begin{tabular}{lccccc}
\hline & \multicolumn{3}{c}{ Digestible } & Dry \\
& IVDMD Protein & yield & Index & matter \\
\hline Forage yield, $\mathrm{Mg} \mathrm{ha}^{-1}$ & 0.07 & $0.54^{* *}$ & $0.99^{* *}$ & $0.20^{* *}$ & $-0.67^{* *}$ \\
IVDMD, $\mathrm{g} \mathrm{kg}^{-1}$ & & -0.01 & $0.18^{*}$ & $0.18^{* *}$ & 0.04 \\
Protein, $\mathrm{g} \mathrm{kg}^{-1}$ & & & $0.54^{* *}$ & $\mathbf{0 . 0 3}$ & $-0.87^{* *}$ \\
Digestible yield, $\mathrm{Mg} \mathrm{ha}^{-1}$ & & & & $0.22^{*}$ & $-0.67^{* *}$ \\
Index & & & & 0.07 \\
\hline $\begin{array}{l}* * \text { Significant at the } 0.05 \text { and } 0.01 \text { levels of probability, respectively. } \\
N=210 .\end{array}$
\end{tabular}

lated to forage yield or protein content. Digestible yield is unsuitable as a criterion for selecting for both yield and quality, because it simply reflects yield differences.

Baker (1988) pointed out that in genotype $x$ environment interaction studies, determining whether there are crossover interactions is more important than determining if genotypic responses are parallel across environments. Since Spearman correlations are correlations of rank, they are a simple but effective means of determining the magnitude of crossovers or changes in rank of genotypes in the test environments. Spearman correlations among the sites confirmed the results of the variance component analyses (Fig. 1). Spearman correlations were high and significant among sites for IVDMD. Spearman correlations were lower but still significant for NE Index values, which reflects the effect of yield. Spearman correlations for forage yield and digestible yield were significant only between Mead and North Platte.

The ranking of the strains for forage yield differed among locations, but some strains (e.g., the experimen-
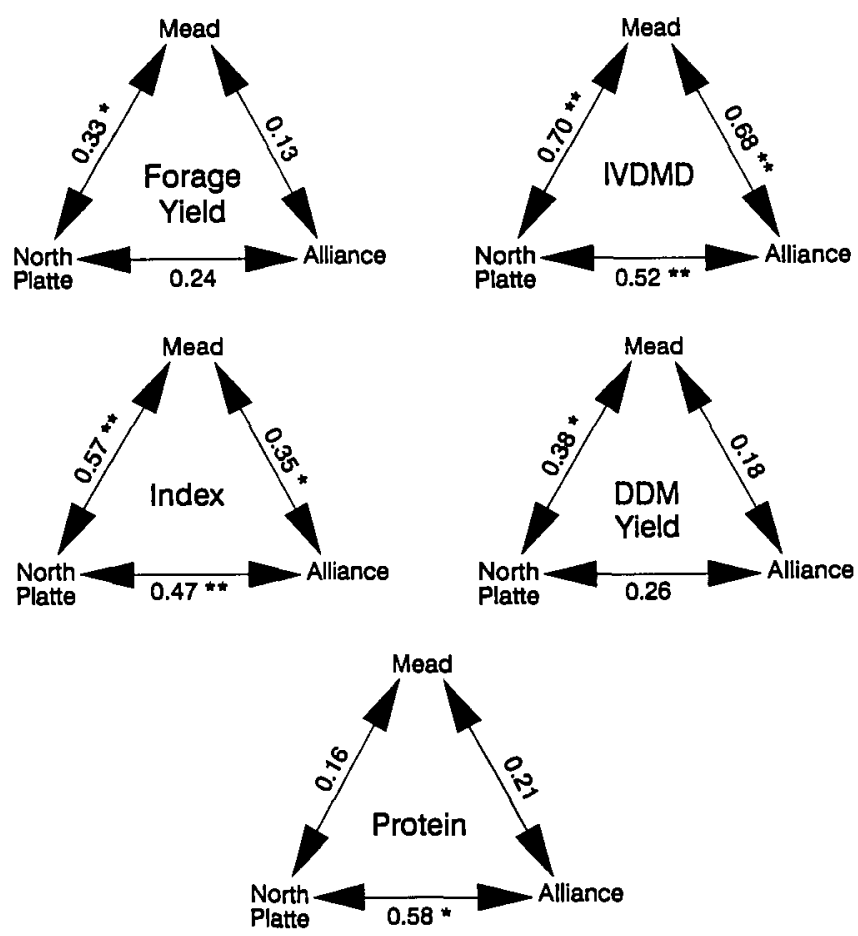

Fig. 1. Spearman correlation coefficients or rank for firstharvest traits of intermediate wheatgrass grown in swards at Mead, North Platte, and Alliance, NE. *,* Significant at the 0.05 and the 0.01 levels of probability, respectively. 
tal strain NE PI N SYN) had good yields in all locations (Table 5). Strains with low yields in one environment usually had low yields in the other environments. With few exceptions, the ranking of the strains for IVDMD in the three locations was similar (Table 6). Ranking of the strains in the three locations for NE Index (data not shown) was consistent with the Spearman correlations.

Results of this study clearly demonstrate that there are significant genetic differences among intermediate wheatgrass cultivars and elite breeding populations grown in swards for first-harvest forage yield, IVDMD, and protein concentration. IVDMD concentrations were relatively stable and consistent across years and locations. These results are consistent with results obtained in spaceplanted germplasm evaluation experiments (Vogel et al., 1986). Forage yields were not as consistent as IVDMD across environments, but some strains ranked consistently at the bottom or in the top one-third of the tests. The results indicate that yield trials are needed across the east-to-west climatic gradient in the Central Great Plains to adequately select the highest-yielding strains for eastern, central, and western areas in this region.

Recent grazing trial results of Moore et al. (1990) demonstrated that differences in IVDMD among intermediate wheatgrasses can have significant impact on cattle gains and beef production per hectare. Included in their grazing trial were the cultivars Slate, Manska, and Oahe (Tables 5 and 6), which were used as checks in this study. Cattle grazing Manska had significantly higher average daily gains and beef production per hectare than cattle grazing Oahe and Slate. The improved gain was believed to be due to Manska's higher IVDMD. Hence, intermediate wheatgrass breeding programs should emphasize improving IVDMD, since IVDMD is a trait for which there is substantial genetic variation, it is stable over environments (locations and years), and it is not negatively associated with forage yield. In addition, improvements in IVDMD can result in significant increases in animal production from intermediate wheatgrass.

Plant breeders often use an array of germplasm including plant introductions and genetic stocks in various stages of development. In this study, we evaluated elite genetic stocks including released cultivars and elite experimental lines from both U.S. and Canadian breeding programs, whereas in a prior study (Vogel et al., 1986), raw germplasm, consisting primarily of previously untested plant introductions was evaluated. Space-planted nurseries are often required with raw germplasm, because of lack of seed. Differences among strains for yield are often larger in space-planted nurseries than in sward trials, because of reduced within-strain plant-to-plant competition.

The range of means for yield and other traits was much greater among the strains in the raw germplasm experiment (Vogel et al., 1986) than among the elite entries in this experiment. For example, in the germplasm evaluation experiments, some strains yielded almost threefold the amount of forage as other strains. In this situation, very large changes in relative yields would be required to produce changes in rank. In contrast, in an elite trial, the range among strains is much narrower and small changes in relative yields can cause changes in rank and produce significant genotype $\times$ environment interaction effects. Spearman rank correlations would be expected
Table 5. Strains of intermediate wheatgrasses with the highest and lowest first harvest forage yields over years and locations and their rank in each location (number of strains $=34$ ).

\begin{tabular}{|c|c|c|c|c|}
\hline \multirow[b]{2}{*}{ Strain $\dagger$} & \multirow{2}{*}{$\begin{array}{c}\text { Mean } \\
\text { Forage yield }\end{array}$} & \multicolumn{3}{|c|}{ Rank } \\
\hline & & Mead & North Platte & Alliance \\
\hline \multicolumn{5}{|c|}{$\mathbf{M g ~ h a}^{-1}$} \\
\hline \multicolumn{5}{|c|}{$\underline{\text { High }}$} \\
\hline $\begin{array}{l}\text { S-9045 } \\
\text { NE PI N Syn } \\
\text { Oahe } \\
\text { Greenar } \\
\text { S-9045 }\end{array}$ & $\begin{array}{l}6.4 \\
6.1 \\
5.8 \\
5.8 \\
5.7\end{array}$ & $\begin{array}{r}14 \\
9 \\
1 \\
33 \\
2\end{array}$ & $\begin{array}{r}5 \\
1 \\
17 \\
26 \\
8\end{array}$ & $\begin{array}{r}1 \\
3 \\
17 \\
2 \\
15\end{array}$ \\
\hline \multicolumn{5}{|c|}{ Low } \\
\hline $\begin{array}{l}\text { NE } 273732 \text { PH } \\
\text { Ree } \\
\text { NE 50 Slate } \\
\text { Luna } \\
\text { Tegmar }\end{array}$ & $\begin{array}{l}5.2 \\
5.1 \\
5.0 \\
4.8 \\
3.8\end{array}$ & $\begin{array}{l}24 \\
32 \\
29 \\
34 \\
35\end{array}$ & $\begin{array}{l}28 \\
23 \\
32 \\
34 \\
35\end{array}$ & $\begin{array}{l}32 \\
22 \\
31 \\
21 \\
35\end{array}$ \\
\hline \multicolumn{5}{|c|}{ Checks } \\
\hline $\begin{array}{l}\text { Slate } \\
\text { Manska } \\
\text { Oahe }\end{array}$ & $\begin{array}{l}5.3 \\
5.3 \\
5.8\end{array}$ & $\begin{array}{r}12 \\
22 \\
1\end{array}$ & $\begin{array}{l}33 \\
30 \\
17\end{array}$ & $\begin{array}{r}8 \\
13 \\
17\end{array}$ \\
\hline
\end{tabular}

$\uparrow$ Four of the five strains with the highest and lowest yields were also in the sets with the highest and lowest digestible yields, respectively.

Table 6. Strains of intermediate wheatgrasses with the highest and lowest first harvest IVDMD over years and locations and their rank in each location (number of strains $=34$ ).

\begin{tabular}{|c|c|c|c|c|}
\hline \multirow[b]{2}{*}{ Strain } & \multirow{2}{*}{$\begin{array}{l}\text { Mean } \\
\text { IVDMD }\end{array}$} & \multicolumn{3}{|c|}{ Rank } \\
\hline & & Mead & North Platte & Alliance \\
\hline \multicolumn{5}{|c|}{$\mathrm{g} \mathrm{kg}^{-1}$} \\
\hline \multicolumn{5}{|c|}{ High } \\
\hline $\begin{array}{l}\text { NE } 273733 \\
\text { NE } 345586 \\
\text { NE NB Syn } \\
\text { NE } 315067 \\
\text { NE } 315353\end{array}$ & $\begin{array}{l}585 \\
584 \\
584 \\
584 \\
582\end{array}$ & $\begin{array}{r}11 \\
2 \\
4 \\
1 \\
3\end{array}$ & $\begin{array}{r}1 \\
14 \\
4 \\
8 \\
3\end{array}$ & $\begin{array}{r}5 \\
1 \\
3 \\
7 \\
14\end{array}$ \\
\hline \multicolumn{5}{|c|}{ Low } \\
\hline $\begin{array}{l}\text { Tegmar } \\
\text { SD 52 } \\
\text { Greenar } \\
\text { Amur } \\
\text { Luna }\end{array}$ & $\begin{array}{l}549 \\
549 \\
547 \\
544 \\
534\end{array}$ & $\begin{array}{l}33 \\
31 \\
32 \\
34 \\
35\end{array}$ & $\begin{array}{l}28 \\
34 \\
27 \\
30 \\
35\end{array}$ & $\begin{array}{l}32 \\
31 \\
34 \\
33 \\
35\end{array}$ \\
\hline \multicolumn{5}{|c|}{ Checks } \\
\hline $\begin{array}{l}\text { Slate } \\
\text { Manska } \\
\text { Oahe }\end{array}$ & $\begin{array}{l}564 \\
581 \\
563\end{array}$ & $\begin{array}{r}27 \\
5 \\
24\end{array}$ & $\begin{array}{l}11 \\
12 \\
20\end{array}$ & $\begin{array}{r}27 \\
2 \\
26\end{array}$ \\
\hline
\end{tabular}

to be lower in trials with elite breeding material than with raw germplasm. Consequently, testing in multiple environments with intermediate wheatgrass, and probably with other grasses as well, is more important when evaluating elite breeding lines than in evaluating less developed germplasm. In both types of evaluation nurseries, IVDMD in intermediate wheatgrass is more stable than yield across environments.

\section{REFERENCES}

Association of Official Agricultural Chemists. 1960. Official methods of analyses of the AOAC. 9th ed. AOAC, Washington, DC.

Baker, Robert J. 1988. Analysis of genotype-environmental interaction in crops. ISI Atlas of Science: Animal and Plant Sciences $1: 1-5$. 
Barkworth, M.E., and D.R. Dewey. 1985. Genomically based genera in the perennial triticeae of North America: Identification and membership. Am. J. Bot. 72:767-776.

Becker, W.A. 1984. Manual of quantitative genetics. 4th ed. Academic Enterprises, Pullman, WA.

Dewey, D.R. 1984. The genome system of classification as a guide to intergeneric hybridization with the perennial Triticeas. p. 209-279. In J.P. Gustafson (ed). Gene manipulation in plant improvement. Plenum Press, New York.

Hanson, A.A. 1972. Grass varieties in the United States. USDA Agric. Handb. 170. U.S. Gov. Print. Office, Washington, DC.

Heinrichs, D.H., T. Lawrence, and F.H.W. Morley. 1962. Breeding for improvement of quantitative characters in Agropyron intermedium (Host.) Beauv. by the polycross method. Can. J. Plant Sci. 42:323-338.

Hitchcock, A.S. 1951. Manual of grasses of the United States. 2nd ed. USDA Misc. Publ. 200. U.S. Gov. Print. Office, Washington, DC.

Karn, J.F., and J.D. Berdahl. 1984. Nutritional, morphological and agronomic characteristics of selected intermediate wheatgrass clones. Can. J. Plant Sci. 42:276-279.

Lawrence, T. 1982. Registration of Clarke intermediate wheatgrass. Crop Sci. 22:898.

Lawson, M.P. 1977. Nebraska's climatic controls, p. 1-6. In M.P. Lawson (ed.) Climatic atlas of Nebraska. Univ. of $\mathrm{Ne}$ braska Press, Lincoln, NE.

Moore, K.H., K.P. Vogel, T.J. Klopfenstein, and B.E. Anderson. 1990. Forage quality of intermediate wheatgrass under grazing. p. 190. In Agronomy abstracts. ASA, Madison, WI.
National Oceanic and Atmospheric Administration. 1982-1983. Climatological data annual summaries, 1982 and 1983. U.S Dep. of Commerce, NOAA, Ashville, NC.

Neild, R.E. 1977. Temperature, p. 10-36. In M.P. Lawson (ed.) Climatic atlas of Nebraska. Univ. of Nebraska Press, Lincoln, NE.

Rice, J.S., and R.B. Brown. 1985. Clonal interactions with harvests and years for forage quality components in intermediate wheatgrass. Crop Sci. 25:47-50.

Roth, L.S. 1971. Development and application of selection criteria for improvement of corn forage. Ph.D. diss. Univ. of Nebraska-Lincoln (Diss. Abstr. 32:6163-B).

Snedecor, G.W., and W.G. Cochran. 1967. Statistical methods. 6th ed. Iowa State Univ. Press, Ames.

Steel, R.G.D., and J.H. Torrie. 1960. Principles and procedures of statistics. McGraw-Hill Book Co., New York.

Thaden, R.T., J.G. Ross, and A. Akyurek. 1975. Variability of in vitro dry matter digestibility in diallel and polycross progeny of intermediate wheatgrass. Crop Sci. 15:375-378.

Tilley, J.M.A., and R.A. Terry. 1963. A two-stage technique of the in vitro dry matter digestibility of forage crops. J. Br. Grassl. Soc. 18:104-111.

Vogel, K.P., P.E. Reece, and J.F.S. Lamb. 1986. Genotype and genotype and genotype $x$ environment interaction effects for forage yield and quality of intermediate wheatgrass. Crop Sci. 26:653-658.

Wurster, M.J., L.D. Kamstra, and J.G. Ross. 1971. Evaluation of cool season grass species and varieties using in vivo and in vitro techniques. Agron. J. 63:241-245. 